\title{
The Voices of Madness
}

\section{Frances Davies and Laura González}

We arrived into Oxford from all corners of the world, on the $30^{\text {th }}$ August 2012. The end of the summer meant that students were not yet on site and Mansfield College, our location for the $5^{\text {th }}$ Global Making Sense of Madness conference, ${ }^{1}$ was slightly eerie, yet inviting. There were about 35 of us, all interested in madness and its complexities. Some of us observed it, some thought about it, some witnessed it and some suffered from it. From the beginning of the event, we attempted to define madness, and, of course, failed. In the process, however, we shared referencesmany of which are in the rich resources cited in this book-and experiences. Selfharm, delirium, schizophrenia, depression, alcoholism, manic-depression, hysteria, multiple personality, addiction, erotic monomania and perversion were some of the partial names we gave madness. We even questioned our own terminology: madness or mental health? We saw madness as an expansive word. This particular debate about naming is followed up by Bernadette V. Russo's chapter in this book, ${ }^{2}$ as she discusses the relationship between a discourse of madness and one of insanity, seeing insanity as historically, culturally and socially belonging more to women as it '[implies] mental defect, a mental incompetence, an inability to reason. ${ }^{3}$ She cites Michael Foucault's Discipline and Punishment in her critique of the powers that sought to 'eliminate the possibility of female madness entirely because it was believed females lacked the mental capacity to be self-aware enough to go mad. ${ }^{4}$ Of course, her precise critique, as well as the discussions we had in Oxford, is part of the reason why the word madness appears in the title of the book, over other possibilities. Self-awareness is one of key features of this volume.

During the three days of the conference, we, as delegates, were introduced to madness from a wide variety of backgrounds. This was not just in terms of the particular madness that was being discussed but also the positions, training and viewpoint of the authors, who came from a variety of backgrounds: from sociology to fine art, the mental health and social care professions and literary criticism. We all felt comfortable sharing disciplines, speaking across them. Despite our positioning, we were all looking for something in the other, something to shake our particular conceptions of madness. This is why the name and ethos of our publisher, Inter-Disciplinary Press, is an apt home for our research. We not only sought to share our context and methodologies-that would be multidisciplinarity - we wanted to create a new object. Our attempt to do so is in this book. At times, finding a common set of meanings was troublesome, as words used in different fields also carry a different sense (see, for example, modernity). These contradictions have been left as provocation, and also reminders that more work and dialogue are needed. There was more to our discussion, however, than finding a common ground for how madness is understood and studied in our 
different fields, or even defining, and working on, this new area-could we call it madness studies?

We were aware that, in May 2013 the controversial fifth edition of the Diagnostic and Statistical Manual of Mental Disorders (DSM-V) would be published. The manual provides a particular view on madness, one we returned to in our work during those three days. Our thoughts on this were an essential driver for the publication of this book, a year after our gathering in Oxford. The DSM defines madness, classifies it in diagnostic categories, which have an ambivalent status; sometimes they help the sufferer to understand, get help and support, manage the suffering - as discussed in Mira Marcinów and Fátima Alves's chapter. At other times, it can be used as a framework to differentiate, to state that someone is other, and not us. A clear exploration and critique of this takes place in the opening chapter of the book by Bruce M. Z. Cohen.

Madness, its study and its critique are global phenomena, as a recent article by Ross White in The Psychologist argues. ${ }^{5}$ The Oxford conference was global too. The geographical locations of delegates and, by extension, of the contributors to this book, offer a fair perspective on the understanding of, and addressing issues related to, madness across different continents and cultural contexts. Yet, despite South American and African perspectives being represented at the conference, our viewpoints do not cover the full breath of the world. Still, they do offer, in one single volume, a wider global and interdisciplinary perspective than most critical studies.

Linked to our interest in madness and our interdisciplinary ambitions, we found three other connecting points in our work. Two of these are represented in the title of the volume: women and art. The third-voice-was an unexpected find in the compilation of this book.

Women face a higher risk of stigmatisation and exclusion than men do when it comes to madness, as is illustrated in various chapters of this book, notably those of Emma Tseris, Jennifer Hedgecock, Nazan Yildiz, Daniela Chana, Russo, and Eleanor Bowen and Laura González. These chapters are specifically gendered, but this does not mean that the others do not apply to women as well. Our book, however, is not exactly about women; we use the word in a provocative way, as we do with madness. What we explore in this volume are patriarchal perceptions and the use of imagery in madness. Throughout history, women have been portrayed as the weaker, less perfect sex. From Bowen and González's chapter examining hysteria as a feminine condition to Hedgecock's current day research illustrating the emotional, psychological, physical and sexual abuse endured by women within motorcycle gangs, each of the texts adds another layer to the understanding of, and enlightenment to, the injustice experienced by women, past and present considered mad. However, these are not new reflections, as shown by many of the authors here represented. Madness is also an old topic to write about; it is something that has existed and has been articulated throughout the ages, especially in literature. 
What makes this book interesting is that this is explored through experiential knowledge - see Yildiz' chapter on Chaucer's Wife of Bath, and Bowen and González's on hysteria - and lay rationalities, or personal narratives - in, for example, Marcinów and Alves's study of madness in Poland and Portugal, and Tseris' exploration of traumatised young women. Yet, we are not exactly writing from a feminist perspective, although there are feminisms within the book. The issues we raise are more related to a concern with voice than a political stance-if the issue of voice could be thought of as apolitical. We are positioned, however, and our position is rooted in care, duty and, of course, knowledge production.

Our second common concern, the binding of culture and distress, was evident before we arrived in Oxford, in the conference panels into which we slotted. The manifold ways in which the context and cultural product affect-both positively and negatively - the suffering we discussed was inspiring, at least to conduct further research. Some of those links are shown in the second part of this book. Following Frances Davies' quantitative research on the links between self-harm and creativity, closing the first contextual part of the book, authors in the second section examine, in particular, the link between madness and art, in literature and visual production. For centuries, artists have been classified as $\mathrm{mad}^{6}{ }^{6}$ stepping away from traditional, acceptable behaviours, with society casting them as eccentric or crazy. It is these artists who have been brave enough to shun traditional society and move away from the expected, potentially causing them, and those around, isolation and stigmatisation. Yet, sometimes, as Katia Mitova reveals, this madness is also related to genius, to colossal steps towards opening more possibilities of articulation and expression. The poet Fernando Pessoa and his heteronyms are a perfect example of this. The syndrome under his name, coined by Mitova, goes beyond gender or feminine characteristics.

Yet, a disturbing issue regarding our exploration of the arts, especially for those of our readers coming from a visual arts background, might be the absence of images. Why that choice? It is simply one of engagement. Including images in this book would have meant reproducing them, and Bowen and Gonzalez, the authors who address visual art in their text, propose and promote a direct engagement with works of art by creating a piece that operates like one. Visual art can also be textual. Paratextual, even. ${ }^{7}$ Still, we do acknowledge that the interface between visual arts and theoretical studies on madness is an area that requires further thought and research, especially in its presentation.

Many of the cultural manifestation discussed, in particular the literary ones, have been heard and read before, sometimes widely-although not always, as is the case with Chana's source materials. What our authors do is provide them with contexts unseen before. The voice of sufferers - and women-has been a surprising thread in most of the chapters. These have not been listened to much, other than through case expositions, scored by the clinician-writers. In our book, we make a space for them. We did not foresee this happening when we were in 
Oxford although, with the hindsight we now have as editors, our common interest is evident. These first person accounts of madness push through the writing, demanding, quite rightly, to tell their story and be heard (see Tseris' work). Often, as in the case of the material Bowen and González examine, we cannot hear the voice; we can only suppose it because the lips are moving. They got closer and attempted some ventriloquism in the hope of liberating the stoppage in the throat.

We finished the conference with a discussion on forgiveness and personal responsibility and although none of the chapters in this book address the issue directly, they all open up a space for personal reflections on each of our agenciesas authors, researchers, workers in our fields, sufferers and readers-and our responsibility in relation to madness, women, and the cultural production exploring them.

When we left Oxford, we were more puzzled than when we arrived. We did not reach a consensus on the main question of what is madness, ${ }^{8}$ and others rapidly proliferated. Our own knowledge base of madness was certainly broadened by the varying takes on the topic, but more questions appeared to be raised than answered. How do we quantify madness? Should it even be quantified? Who has the power to decree another individual is mad? How do we treat and care for madness? How do we live with madness? We went away with the awareness of how much more research is required, while at the same time realising that, being such a contentious and subjective area, we are never all going to agree on it. You see? The issue of voice was there from the beginning, thrusting itself as we prepared proposals for this book.

The process of going from conference to book was compelling, challenging and rewarding. We became experts in time zones and digital communication. Yet, it worked because of our common purpose, our commitment to opening up the discourse on madness, and the knowledge of our shared experience in Oxford. None would have been possible without the space Robert Fisher, Network Founder and Network Leader for Inter-Disciplinary.Net, created for us. We would also like to thank, very warmly, Gonzalo Araoz, our welcoming host in Oxford, leader for the Madness project and a very engaging researcher into the role of collage in wellbeing. Lisa Howard, our editor at Inter-disciplinary Press, provided us with guidance, focus and motivation. Our work would not have been as productive and fulfilling if we did not have her support. Ama Budge provided us, as editors, with critical distance, and her passion and attention, her care and advice on issues of voice-crucial to the texts you are about to read-were very much appreciated. The writers in this volume, mentioned below, make this book. Without them, there would be no publication, no expansion of discourse, no dialogue, no interdisciplinary sharing of knowledge and experience. As editors, we have grown our knowledge of madness and added considerably to our reading list, thanks to the interesting research we were exposed to in this process. It is to the authors we owe the biggest thanks for their generosity and patience with our editorial comings and 
goings. However, we must not forget those who shared our conversations in Oxford but could not be included in this volume, often because they were working on a volume of their own. They are also here, in absentia; their voices helped to shape our thoughts.

The main aim of this book is to provide a platform for the multi-vocal, interdisciplinary perspective on madness we had the privilege to discuss in Oxford. We wanted to make a private, quite small gathering public because the dialogue was relevant to the here and now, to our troubled and conflicted times. The book is, we think, a good read, or, at least, a provocative one. Yet, there is no mistaking that these are writings about intense suffering, with the small mercies that artistic process does sometimes provide. The main questions we raise are; who creates the context for madness? How have women related and continue to relate to this context? Does creativity and cultural production have a special relation to madness?

The book contains two sections. The first, explores the context of madness from rich and diverse points of view. Most of the chapters also address issues pertaining to women. Opening this section is Cohen's chapter: a Marxist critique of the psychiatric system. He positions himself within a social constructionist frame of reference but furthers this critique-that the psychiatric professions have little claim to knowledge - with a Marxist perspective, seeing the categorisation, diagnosis - the DSM - and treatment of madness as a form of control of the dominant ideology. Tseris' chapter examines trauma, the position of the social worker and the plurality of their engagement with clients, as well as the experience of treatment by young women in current day Australia. While the research took place in Australia, the issues discussed and the pain articulated, so evident and sensitively conveyed, are global. Cohen's sociological argument finds, in Tseris' chapter, first hand data and the voice of sufferers. Taking a similar position to Cohen but expanding it further from her own engagement in practice, she proposes to critique the system with intervention from within.

Marcinów and Alves' work is a perfect example of the role of the conference in the development of the book. They met at the 2011 gathering and their respective papers raised pressing questions, which led them to collaborate for this book. They provide a comparative analysis between experiences of mental suffering in Eastern and Western Europe, through the case studies of Poland and Portugal. Like Tseris, they do this through lay accounts, listening to the voice of sufferers. They examine these accounts as a form of knowledge in relation to professional, psychiatric knowledge. Hedgecock's chapter studies a condition not listed in the DSM: love addiction. Yet, intense suffering is evident in the reading of her chapter. She addresses a perspective of madness rarely spoken about and even more seldom studied; the position of women in motorcycle gangs. The last chapter in this section, by Davies, introduces creativity, explored in the context of self-harm, and in relation to impulsivity, perfectionism and emotion dysregulation. She defines 
these concepts and provides primary statistical data that evidences links between them.

Davies' research leads to the second part of the book, on art. This section shows madness in action, as it were, through works, most of which address women, or the feminine. Nazan Yildiz investigates madness in medieval times through the literary example of Geoffrey Chaucer's Wife of Bath in The Canterbury Tales. She explores a common stereotype in written works: the madwoman in the attic. Our volume contains contexts and histories of madness throughout its pages, but its anatomy is not historical or chronological, so Chana's work on contemporary Italian writers follows Yildiz's medieval times. Her sources are less well known and studied than Chaucer-and here lies a large part of the interest of her chapter. The characters in the works of Simona Vinci and Isabella Santacroce-writers named Young Cannibals by critics - share with the Wife of Bath a position of defiance of their context.

Mitova explores literary symptoms of madness. Although by examining Pessoa and other male writers she moves away from the focus held directly on women, she lets his own diagnosis - a deep seated form of hysteria, which is, of course, an affliction referring to the womb - be the starting point towards an exploration of his heteronyms, the expression of which Mitova terms Multiple Personality Order. Despite studying male writers, she claims, quite rightly, that the symptoms contain a position considered feminine, or even beyond gender. Russo's chapter researches the other role taken by women in opposition to The Wife of Bath's defiance: that of the damning complicit, an expression she coins. She studies this, like Yildiz and Chana, in the literary manifestations of women in TsiTsi Dangarembga's work Nervous Conditions, and Charlotte Perkins Gilman's story 'The Yellow Wallpaper.' With Bowen and González, the book draws to a close. In this chapter, the themes of madness, women and art - the visual arts, as well as literature-are retraced retroactively. They explore hysteria, or rather hysteric women, in film, video practice, painting, and the drawings and photographs Dr Charcot's team produced at the Salpêtrière hospital in the nineteenth century. Their text is hysterisised. They are troubled by the voice and its absence and invite the reader, through an intricate writing practice that is non-linear and folded, to breathe and listen.

For us, the process of editing these chapters contained much afterwardness, as our writers took us on journeys that made us 'remember but not transcribe." Afterwardness is a term from the field of psychoanalysis. A clumsy translation from Sigmund Freud's nachträglichkeit, it has also been termed retroaction, deferred action or, in French, après coup. Adam Phillips explains it, as ever, succinctly: 'In one sense, Freud's theory of deferred action can be simply stated: memory is reprinted, so to speak, in accordance with later experience. ${ }^{10} \mathrm{We}$ end our introduction with an invitation to listen, an invitation that is threaded, perpetuated throughout the volume. We hope that, by the time the reader finishes 
the book, or even later, the memory of that invitation is reprinted with the experience of having listened. So, retroactively and in afterwardness, from this introduction, we invite, urge you, our reader, to breathe and listen to the voices that are about to begin speaking.

\section{Notes}

${ }^{1}$ Inter-Disciplinary.net, 5th Global Conference Making Sense of Madness (Oxford, Mansfield College, August 30-September 1, 2012), viewed February 22, 2013, http://www.inter-disciplinary.net/probing-the-boundaries/making-senseof/madness/project-archives/5th/

${ }^{2}$ See Bernadette V. Russo, 'Shackles of a Distant Self and the Damning Complicit' in section 2 of this volume.

${ }^{3}$ Russo, 'Shackles of a Distant Self'.

${ }^{4}$ Russo, 'Shackles of a Distant Self'.

${ }^{5}$ Ross White, 'The Globalisation of Mental Illness', The Psychologist 26.3 (March 2013): 182-185.

${ }^{6}$ See, for example, Sander L. Gilman, 'The Mad Man as Artist:

Medicine, History and Degenerate Art', Journal of Contemporary History 20.4, Medicine, History and Society (October 1985): 575-597; Barry Panter, Mary Lou Panter, Evelyn Virshup and Bernard Virshup, ed. Creativity and Madness: Psychological Studies of Art and Artists (Burbank, CA: AIMED Press, 1996); Shlomo Giora Shoham, Art, Crime and Madness: Gesualdo, Carravagio, Genet, Van Gogh, Artaud (Eastbourne: Sussex Academic Press, 2002); José Guimón, Art and Madness (Aurora, CO: The Davies Group Publishers, 2006).

${ }^{7}$ Eleanor Bowen, 'Drawing and Longing: Proposal for Drawing as Paratext', Drawing Out 2012, viewed March 27, 2013, $\mathrm{http} / / /$ process.arts.ac.uk/content/drawing-and-longing-proposal-drawing-paratext.

${ }^{8}$ We did not reach a consensus, even if some of us discussed Darian Leader's work, offering a possible solution. See Darian Leader, What is Madness? (London: Penguin, 2011).

${ }^{9}$ Adam Phillips, On Flirtation (London: Faber and Faber, 1994), 33.

${ }^{10}$ Phillips, On Flirtation, 33.

\section{Bibliography}

Bowen, Eleanor. 'Drawing and Longing: Proposal for Drawing as Paratext'. Drawing Out 2012. Viewed March 27, 2013. http://process.arts.ac.uk/content/drawing-and-longing-proposal-drawing-paratext. 
Gilman, Sander L. 'The Mad Man as Artist: Medicine, History and Degenerate Art'. Journal of Contemporary History 20.4. Medicine, History and Society (October 1985): 575-597.

Guimón, José. Art and Madness. Aurora, CO: The Davies Group Publishers, 2006.

Inter-Disciplinary.net. 5th Global Conference Making Sense of Madness. Mansfield College, Oxford, 30 August-1 September 2012. Viewed February 22, 2013. http://www.inter-disciplinary.net/probing-the-boundaries/making-senseof/madness/project-archives/5th/.

Leader, Darian. What is Madness? London: Penguin, 2011.

Panter, Barry, Mary Lou Panter, Evelyn Virshup and Bernard Virshup, ed. Creativity and Madness: Psychological Studies of Art and Artists. Burbank, CA: AIMED Press, 1996.

Phillips, Adam. On Flirtation. London: Faber and Faber, 1994.

Shoham, Shlomo Giora. Art, Crime and Madness: Gesualdo, Carravagio, Genet, Van Gogh, Artaud. Eastbourne: Sussex Academic Press, 2002.

White, Ross. 'The Globalisation of Mental Illness'. The Psychologist 26.3 (March 2013): 182-185. 